\title{
The Chemistry of MSME and Digital Platforms
}

\author{
Creator: \\ Muhammad.Alvin.Arkananta.Syam/130119055/KP-A
}

Micro, Small and Medium Enterprise or we could say it MSME has been a huge breakthrough for contribution in improving Indonesian Economy, Even when the pandemic started, MSME in Indonesia are actually growing rapid nowadays. The reason behind this undoubtedly rapid growth is because larger companies within the pandemic situation tend to lay off a huge deal of worker, so the one that had been laid off start to open a new business making it from scratch, Culinary Sector is the one responsible for the rapid growth of MSME in Indonesia these days. In general, the citizen of Indonesia think that if they choose Culinary for their business because it's easy to make, with cheaper resources and less effort to make. But there is one shortcoming that average Indonesian citizen who start this business didn't think about, it's already polluted (Polluted in here means for ornamental word) The Culinary Business itself before the pandemic had to many competitors, and then when the pandemic spread in Indonesia it just got worse for Culinary Industry.

With that said, in its publication, the Central Bureau of Statistics of the Republic of Indonesia (Indonesian: Badan Pusat Statistik/ BPS) explained that the Indonesia economy experienced deflation of $0.1 \%$ in July 2020. The food, beverage, and tobacco group experienced deflation of $0.79 \%$ and contributed to deflation of $0.19 \%$. Foodstuffs that contributed to deflation included shallots, broiled chicken, rice, garlic, cayenne pepper and sugar. This deflation in food and beverages indicates a decline in demand for food. Surely with this data, it can be proven how the chaotic/polluted Culinary Business can lead to a decrease in demand for foodstuffs. Due to the same concept in every MSME with the menu being mainstream, while the middle and upper income groups whose income is not disturbed tend to choose to save rather than spend their money, considering that no one knows when the Covid-19 pandemic will end and when the situation will return to normal. The tendency to save in the middle to upper class is increasing, as seen in the growth in the amount of money in circulation and deposits above IDR 1 billion. The same can be seen in the number of visits to shopping centers with a range of only $30-40 \%$.

The results of a survey conducted by the Central Bureau of Statistics of the Republic of Indonesia (September 2020) explained that there was a decrease in the income of micro and small businesses by $84 \%$ and $82 \%$ in medium and large businesses. The sharpest declines were in the accommodation, food and beverage, other services, transportation and warehousing services, construction, manufacturing, and trade sectors. Furthermore, the results of a survey conducted by the Asian Development Bank (April-May 2020) in 4 countries such as Indonesia, the Philippines, Thailand and Laos involving 3,831MSME respondents explained that the contribution of MSMEs to Gross Domestic Product in the 4 countries was more than $50 \%$. The imposition of regional restrictions had a negative impact on MSMEs, but some MSMEs were still operating despite a decrease on the income of more than $40 \%$. Large scale reduction of workers was carried out in March-June 2020 and continued until October 2020.

The recovery of the ultra-micro and MSME sectors is very urgent amidst the pressure of the Covid-19 pandemic, the solution to this very problem is digitalization, because it were the key to entrepreneurs surviving and develop amid the Covid-19 pandemic. Efforts to digitize MSMEs need to be maintained in various ways, including consistent and routine mentoring by e-commerce companies. Ultra-micro financing based on digital technology is intended to 
accelerate penetration and financial inclusion, considering that ultra-micro business actors still have difficulty accessing bank financing due to various factors, such as not having a bank account, a location that is difficult to reach, or a very small business scale. Digital Technology is increasingly intertwined with a previously unseen advantages. A number of start-ups and ecommerce players, such as Tokopedia, Shopee, Bli-Bli and the others, are serious about empowering small shops and MSMEs. Various strategies have been carried out by players to stimulate MSME or SME. Efforts to digitize MSMEs needed to be maintained in various ways, including consistent and routine mentoring by e-commerce companies. Due to their strategic role in development, MSMEs must continue to be developed. There should be mutual reinforcement between MSMEs and large businesses in the context of distribution and realizing the greatest possibility of prosperity for the entire community. The government must direct, guide, protect and foster the business climate. One of the solutions to this very problem is through business partnerships between macro, small and medium entrepreneurs and related parties. It is hoped that a mutualistic symbiosis will soon be formed so that the shortcoming stuff, limitations and problems above can be resolved immediately.

MSMEs need to be continuously encouraged so that they can be integrated into the national Production system or global supply chain. MSMEs must be able to work on local advantages to produce special products so that they can be more competitive in both the domestic market and the international market. This kind of pattern has long been applied in Japan, China and South Korea. Several regions in Indonesia have domestic advantages, such as a wealth of unprocessed marine products, agriculture, plantations, and others. Thus, MSMEs need to develop these unprocessed products into special products to fill the global market. The market for special products is a form of market that must be worked on by MSMEs, considering that the uniqueness or locality of MSME products in the creative field has its own selling value compared to mass manufactured products. Hereby, the digital platforms is the key to the survival of MSMEs in Indonesia, running a good relationship with macro companies making it easier for MSMEs player to access social media or streaming platforms for operational need or to promote their products. The Government also takes a big role in developing MSMEs, such as providing facilities and infrastructure, important education that can be delivered through events such as talk show with speaker who are experienced in the field of MSMEs. Within short time, Indonesia Economics will return to normal.

\section{REFERENCE}

Tayibnapis, A. Z., Wuryaningsih, L. E., \& Gora, R. (2021). Medium, Small and Medium Enterprises and Digital Platforms. South Asian Journal of Social Studies and Economics, 10(2), 10-19. https://doi.org/10.9734/sajsse/2021/v10i230258

https://www.aprilasia.com/id/our-media/artikel/program-msme-april-fokus-padaperlindungan-dan-pemulihan-umkm-di-tengah-covid-19 